\title{
A morphohistological and histochemical study of hatchery-reared European hake, Merluccius merluccius (Linnaeus, 1758), during the lecitho-exotrophic larval phase
}

\author{
JUAN B. ORTIZ-DELGADO ${ }^{1}$, JOSÉ IGLESIAS ${ }^{2}$, FRANCISCO J. SÁNCHEZ², \\ ROSA CAL $^{2}$, M. JESUS LAGO ${ }^{2}$, JUAN J. OTERO ${ }^{2}$ and CARMEN SARASQUETE ${ }^{1}$ \\ ${ }^{1}$ Instituto de Ciencias Marinas de Andalucía - CSIC, Campus Universitario Rio San Pedro, Apdo Oficial, \\ 11510 Puerto Real, Cádiz, Spain. E-mail: carmen.sarasquete@icman.csic.es \\ ${ }^{2}$ Instituto Español de Oceanografía, PO Box 1552, Cabo Estai, Canido, Vigo, Pontevedra, Spain.
}

\begin{abstract}
SUMMARY: The larval development of reared European hake, Merluccius merluccius (Linnaeus, 1758), during the lecithotrophic phase, from hatching until 5 days post-hatching (dph), and throughout the endo-exotrophic feeding phase (6-10 dph) was studied by histology and histochemistry. Many crucial morphological, cellular and tissular changes were observed during both feeding phases, mostly those related to digestive and visual ontogenetic events, such as differentiation of buccopharyngeal cavity and eye development (at hatching); pigmentation and differentiation of cone-photoreceptors (4 $\mathrm{dph}$ ); opening of the mouth and anus, appearance of intestinal valves (5-6 dph); presence of buccopharyngo-esophageal (5-6 dph) and intestinal (9 dph) mucous cells; folding of intestinal mucosa $(6 \mathrm{dph}) ;$ development of regional specific digestive musculature $(6 \mathrm{dph})$; typical structure and functionality of the liver (sinusoids, biliary and pancreatic ducts, glycogen, protein and lipid reserves) (4-6 dph); and characteristic acinar distribution pattern of eosinophilic zymogen granules of the exocrine pancreas $(6 \mathrm{dph})$. Between 9 and $10 \mathrm{dph}$, the hake larvae showed evident signs of lipid absorption within enterocytes of the anterior intestinal region and a remarkable process of pynocitosis and intracellular digestion was detected in the posterior intestine (supranuclear inclusions or acidophilic protein vesicles). In hake larvae at $10 \mathrm{dph}$, a proliferation of renal tubules, spleen differentiation and gill development, as well as the presence of the first thyroid follicle, were clearly distinguished. At this time, stomach gastric gland differentiation was not detected and endocrine pancreas and gill lamellae were not evidenced. However, and interestingly, swim bladder and eyes (developing rods) were well differentiated in larval development from $9 \mathrm{dph}$ onwards. In summary, in European hake larval development during the endo-exogenous feeding phase and especially at 9 to $10 \mathrm{dph}$, most systems, organs and tissues were well differentiated. Particularly, digestive and visual systems were developed and physiologically functional some days before the start of the exogenous feeding phase.
\end{abstract}

Keywords: European hake, Merluccius merluccius, larvae, histology, histochemistry, ontogeny, yolk sac, endo-exotrophic feeding, visual acuity.

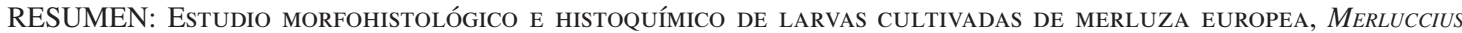
MERLUCCIUS (LINNAEUS, 1758), DURANTE LA FASE LECITO-EXOTRÓFICA. - Se ha realizado un estudio histológico e histoquímico del desarrollo larvario de la merluza europea, Merluccius merluccius (Linnaeus, 1758) durante la fase lecitotrófica, desde la eclosión hasta los 5 días post-eclosión -dpe-, y en la fase endo-exotrófica (larvas de 6-10 dpe). Durante ambas fases alimentarias se han observado importantes cambios morfológicos, celulares y tisulares, principalmente aquellos relacionados con la ontogenia digestiva y visual, tales como: la diferenciación de la cavidad bucofaríngea y desarrollo y diferenciación ocular (en el momento de la eclosión); la pigmentación y diferenciación de fotorreceptores tipo conos (4 dpe); la apertura de la boca y ano, la aparición de válvulas intestinales (5-6 dpe); la presencia de células mucosas secretoras en la cavidad bucofaríngea-esofágica (5-6 dpe) e intestinal ( 9 dpe); el plegamiento de la mucosa intestinal (6 dpe) y el desarrollo de musculatura digestiva regional específica (6 dpe); el desarrollo de la estructura típica y funcionalidad hepática (sinusoides, conductos biliares y pancreáticos, glucógeno y reservas lipídicas y proteicas) (4-6 dpe), y el patrón de distribución acinar característico de gránulos de zimógeno eosinófilos en el páncreas exocrino (6 dpe). Entre 9-10 dpe, las larvas muestran evidentes signos 
de absorción lipídica en los enterocitos de la región anterior intestinal, así como un marcado proceso de pinocitosis y digestión intracelular en el intestino posterior (inclusiones supranucleares o vesículas proteicas acidófilas). En larvas de 10 dpe se detecta una proliferación de túbulos renales y una diferenciación y desarrollo esplénico, así como la presencia del primer folículo tiroideo. Durante el periodo estudiado, no se ha observado ni la diferenciación de glándulas gástricas estomacales, ni el desarrollo del páncreas endocrino o la presencia de lamelas branquiales. Sin embargo, la vejiga natatoria y el sistema visual, caracterizado por la presencia de bastones, están ya diferenciados a partir de 9 dpe. En resumen, durante el desarrollo larvario de la merluza Europea, en la fase de alimentación endo-exotrófica y especialmente a los 9-10 dpe, la mayoría de los sistemas, órganos y tejidos están bien diferenciados y desarrollados. En particular, algunos días antes de comenzar la fase exotrófica del desarrollo larvario, los sistemas digestivo y visual están bien desarrollados y son fisiológicamente funcionales.

Palabras clave: merluza europea, Merluccius merluccius, larvas, histología, histoquímica, ontogenia, saco vitelino, alimentación endo-exotrófica, agudeza visual.

\section{INTRODUCTION}

The European hake, Merluccius merluccius (Linnaeus, 1758), is an important commercial gadid species widely distributed in the northeast Atlantic Ocean and Mediterranean Sea. It is one of the most abundant demersal fish species in landings of the Spanish coasts (Alheit and Pitcher 1995, Sánchez et al. 2007, Iglesias et al. 2010). Owing to progressive decreasing catches since the 1960s (FAO 2005, Lloris et al. 2005), and because this species is well adapted to warm climates and has high growing rates and competitive market prices (Casey and Pereiro 1995, Oliver and Massuti 1995, Recassens et al. 1998, Arneri and Morales-Nin 2000, Olivar et al. 2003, Morales-Nin et al. 2005, Palomera et al. 2005), the European hake is considered a promising species for diversification in marine aquaculture (Bjelland and Skiftesvik 2006, Iglesias et al. 2010, Sánchez et al. 2011). Most studies related to reproductive aspects of this species were performed on wild specimens (Murua and Saborido-Rey 2003, Recassens et al. 2008). However, in comparison with other important commercial species, knowledge on its reproductive biology in captivity (Groisson 2010), an important prerequisite for successful spawning and larval rearing, is still scarce. This is mainly because M. merluccius is very sensitive to handling and difficult to keep alive after capture. For these reasons, to the best of our knowledge, only two broodstocks are currently maintained in captivity, one established in Brekke (Norway) and one established in Spain in 2009 (Spanish Institute of Oceanography/IEO, Vigo). Moreover, as described for other several cultured fish, high mortality rates during larval hatchery-rearing conditions, particularly during the live prey exogenous feeding period, is a significant obstacle for industrial farming and commercial exploitation of this species (Bjelland and Skiftesvik 2006, Iglesias et al. 2010, Sánchez et al. 2011).

Fish undergo major morphological and cellular changes during the first months of life. The transition from yolk-sac stage to actively feeding larvae is considered to be the most critical event during the early life of fishes. The beginning of the exogenous feeding is a key point for the larva, being related to high mortality rates. The sensitivity of larvae to low food intake, especially following yolk absorption, can significantly influence their chances of survival. Main organs and organ-systems become functional by first feeding and differentiate during the larval stage and metamorphosis (Falk-Petersen 2005). There are inter-specific variations in the timing of organ formation, developing and functionality of different systems, organs and tissues, which depend on several genetic, nutritional and/or environment factors (Dinis et al. 1999, Ribeiro et al. 1999, Falk-Petersen 2005, Gisbert et al. 2008, Zambonino-Infante et al. 2008, between others). It is important to note that, in spite of significant differences in rates of development of organs and systems in many fish species, the formation of the digestive tract is completed towards the end of the larval stage and juvenile metamorphosis, while the cytological differentiation takes place earlier than the differentiation of tissue and anatomy (Kuz'mina and Gel'man 1998). During fish ontogeny, the main factors affecting feeding success, growth and healthy larval survival are mainly related to gut development and functionality, swimming capabilities and visual acuity. As larval development advances, gut widening takes places, which is a factor as important as mouth size for determining the ingestion of prey. Folds appear in the gut, providing additional space for accumulating prey and favouring food retention (Falk-Petersen 2005). The good swimming capability of hake larvae is due to fast development of the caudal peduncle, for assisting surely during predation activities (Palomera et al. 2005). Pectoral and pelvic fins start to form and are functional at first feeding (Bjelland and Skiftesvik 2006). The swim bladder is important in larval fish development, as it controls buoyancy and makes swimming activity and prey capture more energy efficient (Bjelland and Skiftesvik 2006).

Interestingly, actively swimming predators depend heavily on sensory organs and visual acuity for successful feeding behaviour (Blaxter 1986, Kawamura 1984, Bozzano and Catalán 2002). Fish larvae are usually visual feeders, indicating that vision plays an important role in larval orientation at this stage. The most important changes in the eye structure occur during the lecitotrophic phase, as a preparation for prey capture. These changes are coincident with the development of the digestive system to start feeding (Roo et al. 1999). The distribution pattern of cells in the ganglion layer of retina varies throughout fish life (Sandy and Blaxter 1980, Kawamura 1984, Blaxter 1986, Powers and Raymon 1990, Haacke et al. 2001, Mas-Riera 1991, Bozzano and Catalán 2002, Kawamura et al. 1984, 2003, 
Morote et al. 2011). Nocturnal feeding activity is unusual in fish larvae (Last, 1980). Large eyes and lenses provide higher sensitivity to fish and hake larvae could be better equipped than other fish species for vision at low light levels (Bozzano and Catalán 2002, Morote et al. 2008, 2011). In European hake larvae, taking into account values of optical sensitivity reported recently, it has been pointed out that this is a crepuscular rather than diurnal species (Land and Nilsson 2002, Morote et al. 2011). Development of the retina differs among fish species and rods may appear before twin cones or vice versa (Omura et al. 1997). In most fish species the eyes become fully pigmented and functional when first feeding is initiated; and a pure-cone-retina appears to be sufficient for that purpose, while rods and twin cones appear at metamorphosis (Blaxter 1986). Rods provide a better vision under low intensity levels (Kawamura 1984) and they are much more photosensitive than cones, which are related to acute form vision. High sensitivity due to rods could be involved in movement perception, and may be particularly important in predator avoidance (Blaxter 1986, Kawamura et al. 1984, 2003, Morote et al. 2011).

The development of the European hake, Merluccius merluccius, for aquaculture is still at an early stage. More research is required but with a healthy broodstock in captivity, the chances of success have increased. The aim of this study is to provide an overview of the digestive tract morphogenesis and parallel development of eyes and other organs and tissues (liver, pancreas, swim and gall bladders, gills, heart, kidney, endocrine system) during the ontogeny and especially through the lecitotrophic (0-5 days post-hatching [dph]) and endoexogenous feeding phase (6-10 dph) of hatchery-reared hake larvae. The distribution of carbohydrates, proteins and neutral lipids is also shown in order to improve knowledge of the dynamics of the physiological state during larval ontogenetic development of hatcheryreared European hake larvae.

\section{MATERIALS AND METHODS}

A reproductive stock of European hake, Merluccius merluccius, from wild catches was kept (IEO, Vigo, NW Spain) in tanks in an open flow-through sea water system according to management procedures reported by Iglesias et al. (2010). After spontaneous spawning, in April 2010, floating fertilized eggs were incubated with moderate aeration, connected to an open water circuit. Hatching of hake larvae was detected after 4 days of incubation period at $14^{\circ} \mathrm{C}$. Larvae at $6 \mathrm{dph}$ were transferred to rearing tanks $(500 \mathrm{~L})$ connected to a stagnant green water system (1/3 renovation every two days). Temperature, salinity, oxygen concentration and density of prey were recorded daily. Larvae (10 per L) were fed with Brachionus plicatilis (2 rotifers per $\mathrm{mL}$ ) previously enriched with microalgae Isochrysis galbana (150000 cells per mL) (Sánchez et al. 2011). Larvae showed a progressive increase in development and growth, from $3.20 \mathrm{~mm}$ of total length/TL $(0 \mathrm{dph})$ to $4.15 \mathrm{~mm}$ (6 dph) and reaching $4.30 \mathrm{~mm}(9-10 \mathrm{dph})$. Oil globule and yolk sac length ranged between 0.27 and $1.05 \mathrm{~mm}(0 \mathrm{dph})$ and 0.14 and $0.33 \mathrm{~mm}(6 \mathrm{dph})$, respectively. From hatching to $1 \mathrm{dph}$, larvae adopted a vertical position in the water column and remained inactive with passive swimming behaviour. At 2 dph larvae moved freely in the water column. First feeding was observed from $6 \mathrm{dph}$ and from this time (endoexogenous feeding phase) hake larvae showed good mobility and swimming activity and were capable of capturing prey with quick and precise movements (Sánchez et al. 2011). From 10 dph onwards, a high percentage of larvae showed the oil globule not adhered (freely moving in the yolk; not located in the posterior part of the yolk sac) which caused high mortalities (Iglesias pers. com.). Zootechniques to improve larval development, nutrition, growth and survival rates (broodstock and larvae feeding protocols, temperature and light intensity, among other rearing limiting factors) are at present being optimized.

For morphohistological and histochemical analysis, hake larvae from hatching $(0 \mathrm{dph})$ to $10 \mathrm{dph}(\mathrm{n}=15$ per day) were fixed in $4 \%$ formaldehyde in $0.1 \mathrm{M}$ phosphate buffer ( $\mathrm{pH}$ 7.2), embedded in paraffin wax for sagittal and transversal sections, and serially cut at 5 to $7 \mu \mathrm{m}$. For morphological studies, sections were stained with Harris' Haematoxylin-Eosin (H-E), Harris' Haematoxylin-VOF (VOF: Light Green, Orange G, Acid Fuchsin), and Harris' Haematoxylin-VOF type III-G.S. (VOF III-G.S.: Light or Fast Green, Orange G, Acid Fuchsin and Methyl Blue) (Sarasquete and Gutiérrez 2005). Specific histochemical reactions for carbohydrates were PAS and diastase-PAS for glycogen, and/ or neutral mucosubstances or glycoproteins and Alcian blue ( $\mathrm{pH} 2.5,1$ and 0.5 ) for acidic (carboxylated and sulphated) mucosubstances or glycoproteins. Bromophenol blue staining was used for detecting proteins in general. Histochemical reactions for proteins rich in amino acids were: 1, 2- napthoquinone-4-sulphonic acid salt sodium (NQS) for arginine; p-dimethylaminobenzaldehyde for tryptophan; ferric ferricyanide Fe III for cysteine, and thioglycolate-potassium ferricyanide Fe III for cystine. These histochemical methods were carried out according to monographs by Martoja and Martoja-Pierson (1970) and Pearse (1985).

\section{RESULTS}

During endotrophic stage 1, or the lecitotrophic phase (from hatching, $0 \mathrm{dph}$ to $5 \mathrm{dph}$ ), the mouth and the anus were closed (yolk-oil globule reserves). As visualized at macroscopic and microscopic levels, in newly hatched larvae, eyes were not pigmented; fins were not present, and the body was surrounded by a wide primordial finfold. At hatching, the pigmentation pattern consisted of scattered pigment cells around the yolk, oil globule, head and trunk. Eyes showed differentiation with initial stages of pigmentation around 2 
TABLE 1. - Schematic synthesis of the main ontogenetic events occurring in the European hake, Merluccius merluccius, larvae during endotrophic (stage 1) and endo-exotrophic (stage 2) phases. Dph: days post-hatching; Ai: anterior intestine; Bphc: buccopharyngeal cavity; Oe, oesophagus; Og: oil globule; Mc: mucous cells; Pb: periblast; Ps: pyloric sphincter; St: stomach; Pi: posterior intestine; Hc: hepatocytes; Ep: exocrine pancreas; Tf: tyroid follicle: Ym: yolk matrix or yolk mass; YS: yolk sac; YSL: yolk syncytial layer; Zg: zymogen granules.

\begin{tabular}{|c|c|}
\hline & Stage 1 (0-5 dph) \\
\hline Endogenous reserves & $\begin{array}{l}\text { Homogeneous acidophilic yolk sac with a single and } \\
\text { large oil globule, and both surrounded by the yolk } \\
\text { syncytial layer or periblast }(0-2) \text {. Vacuolization and } \\
\text { resorption of yolk matrix and Og (4). }\end{array}$ \\
\hline Digestive system & $\begin{array}{l}\text { Mouth and anus closed. Straight and undifferentiated } \\
\text { gut tubular segment; intestinal loop beginning (4). } \\
\text { Mc and microvilli-brush border are not observed. }\end{array}$ \\
\hline
\end{tabular}

Accessory digestive glands

Primordium of the liver, biliary system and pancreas at $4 \mathrm{dph}$ as a mass of basophilic cells under differentiation and developing.

Swim bladder

Eye

Gills

Heart

Kidney and urinary bladder

Spleen

Endocrine elements

Primordial swim bladder seen (1). Early development of gas gland and rete mirabile (4).

Differentiation at hatching. Pigmentation (4).

Gill anlage visible from 1 dph onwards. Chondrogenesis starting.

Pericardial cavity showing a tubular structure at hatching. Four compartments discernible and differentiating (4). Sketch of atrioventricular valve and trabeculae first seen in the ventricle (4).

Urinary bladder present at hatching. Primordial pronephric present and few haematopoietic cells seen. Renal corpuscle visible (4).

Spleen anlage visible (4).
Stage 2 (6-10 dph)

YS still present with an acidophilic granular remaining yolk matrix (scarce periblast) connected with functional liver (10).

Mouth and anus opened (6). Buccopharyngeal cavity, oesophagus and intestine differentiated (6). Appearance of mucous cells in Bphc (6). Elongation, appearance of longitudinal folds and $\mathrm{Mc}$ and presence of primordial Ps and external circular layer of muscle in Oe (6). Stomach develops and becomes folded. Connective tissue and circular layer of muscle cells surrounding St mucosa (9). Thickening of mucosal layer (10). Gastric glands are absent (10). Intestinal loop evident (4). Presence of intestinal valve between $\mathrm{Ai}$ and Pi (6). Mc seen in Ai and Pi (9). Appearance of acidophilic protein inclusions in enterocytes of $\mathrm{Pi}(10)$ and first signs of intestinal lipid absorption in Ai with epithelial brush border (9).

Hepatocytes and exocrine pancreas differentiates. $\mathrm{Hc}$ packet between sinusoids showing glycogen and protein granules and lipid vacuoles within hepatic cytoplasm (6). Acinar cell distribution of the exocrine pancreas with accumulation of acidophilic-proteic Zg (6). Gall bladder anlage and choledochus visible (4).

Complete development of swim bladder (10).

Photoreceptors (cones) differentiation (4) and developing rods (6).

Appearance of primordial gill filaments (4). Lamellae absent (10).

Blood cells circulating and atrioventricular valve formed (6).

Several renal tubules immersed in interstitial tissue (6). Proliferation of renal tubules (9).

Pancreatic islets (endocrine pancreas) still absent. First thyroid follicle visible (10). dph. Fins began to differentiate and first sketch of jaws appeared at $3 \mathrm{dph}$. From $4 \mathrm{dph}$, the larvae had welldifferentiated, developed and pigmented eyes and the notochord, and dorsal part of the digestive tract was spotted with melanophores (Table 1; Figs. 1 to 3).

\section{Yolk sac, digestive tract, accessory organs}

The main ontogenetic events occurring in the European hake larval development are summarized in Table 1 and Figures 1 to 3 . At hatching, hake larvae had an acidophilic yolk sac surrounded by the periblast or yolk syncytial layer of squamous epithelium. The yolk sac had a matrix or yolk mass containing neutral glycoproteins, glycogen, proteins, and an evident single large oil globule composed of neutral lipids and both yolk-structures surrounded by the periblast. The epithelium of this yolk layer consisted of squamous or flattened epithelial cells arranged in layers upon a basement membrane. Only one layer is in contact with the basement membrane; the other layers adhere to one another to maintain structural integrity. In newly hatched hake larvae, the epidermis consisted of two layers of squamous cells, and between mesoderm and epidermis a large fluid-filled space, a sub-dermal space with collagen small fibres, pigment cells and fibroblast, was conspicuous (Fig. 1A and B).

At hatching, the digestive tract was visible as a simple tubular segment, above the yolk sac, but undifferentiated into specific gut regions (Fig. 1A-C). Differentiation of the liver, pancreas, and biliary system was detected from $4 \mathrm{dph}$. The rudimentary liver and pancreas appeared as a cord-like structure, lying between the digestive duct and the yolk-sac wall close 

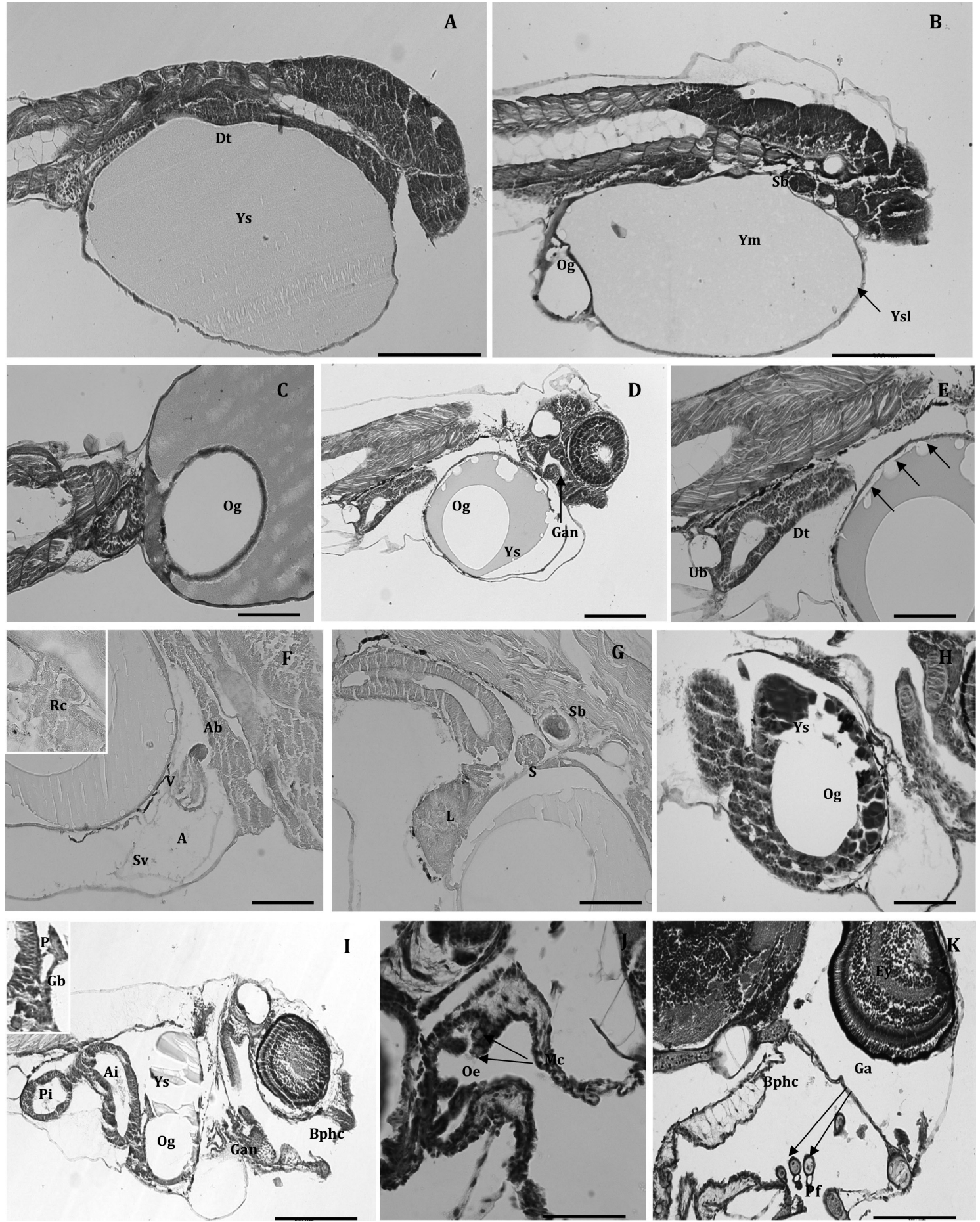

FIG. 1. - Histological sections during larval development of the European hake, Merluccius merluccius. Days post-hatching: dph. A, B) 0 and 1 dph, respectively. Scale bar: 200 um; C) 2 dph showing an eosinophilic and homogeneous yolk matrix and adhered lipid droplet, close to the digestive duct. Periblast enclosing the yolk-sac larvae as well as surrounding the oil globule. Scale bar: $50 \mu \mathrm{m}$; D-G) by 4 dph larvae showing a still undifferentiated and straight digestive tract and a vacuolated (arrowheads) yolk mass with a reduced volume. Primordial hepatic cells were detected. Spleen and kidney are developing and a renal glomerulus is first seen at $4 \mathrm{dph}$. Exocrine pancreatic portion with acidophilic zymogen granules and gall bladder are first seen at $4 \mathrm{dph}$. The four heart chambers were distinguished. Scale bar: (D) $200 \mu \mathrm{m}$, (E to G) 100 um; H, I) larvae at $6 \mathrm{dph}$ showing a regionally differentiated digestive system and the mouth and anus opened. Heterogeneously fragmented yolk matrix and oil globule are still present. Primordial gill anlage is evident. Scale bar: 100 and 200 um respectively; J, K) larvae, showing mucous cells in the oesophagus at $8 \mathrm{dph}(\mathrm{J})$ and gills with primordial filaments in larvae on $9 \mathrm{dph}$, showing developed eyes (K). Scale bar: 500 and 100 um respectively (Ab: aortic bulb; A: auricle; Ai: anterior intestine; Bphc: buccopharyngeal cavity; Dt: digestive tract; Ey: eye; Gan: gill anlage; Ga: gill arches; Gb: gall bladder; L: liver; Mc, mucous cells; Og: oil globule; Oe: oesophagus; P: pancreas; Pf: primordial filaments; Pi: posterior intestine; Rc: renal corpuscle; Sb: swim bladder; Sv: sinus venosus; S: spleen; Ub: urinary bladder; V: ventricle; Ym: yolk matrix; Ys: yolk sac; Ysl: yolk syncytial layer). 

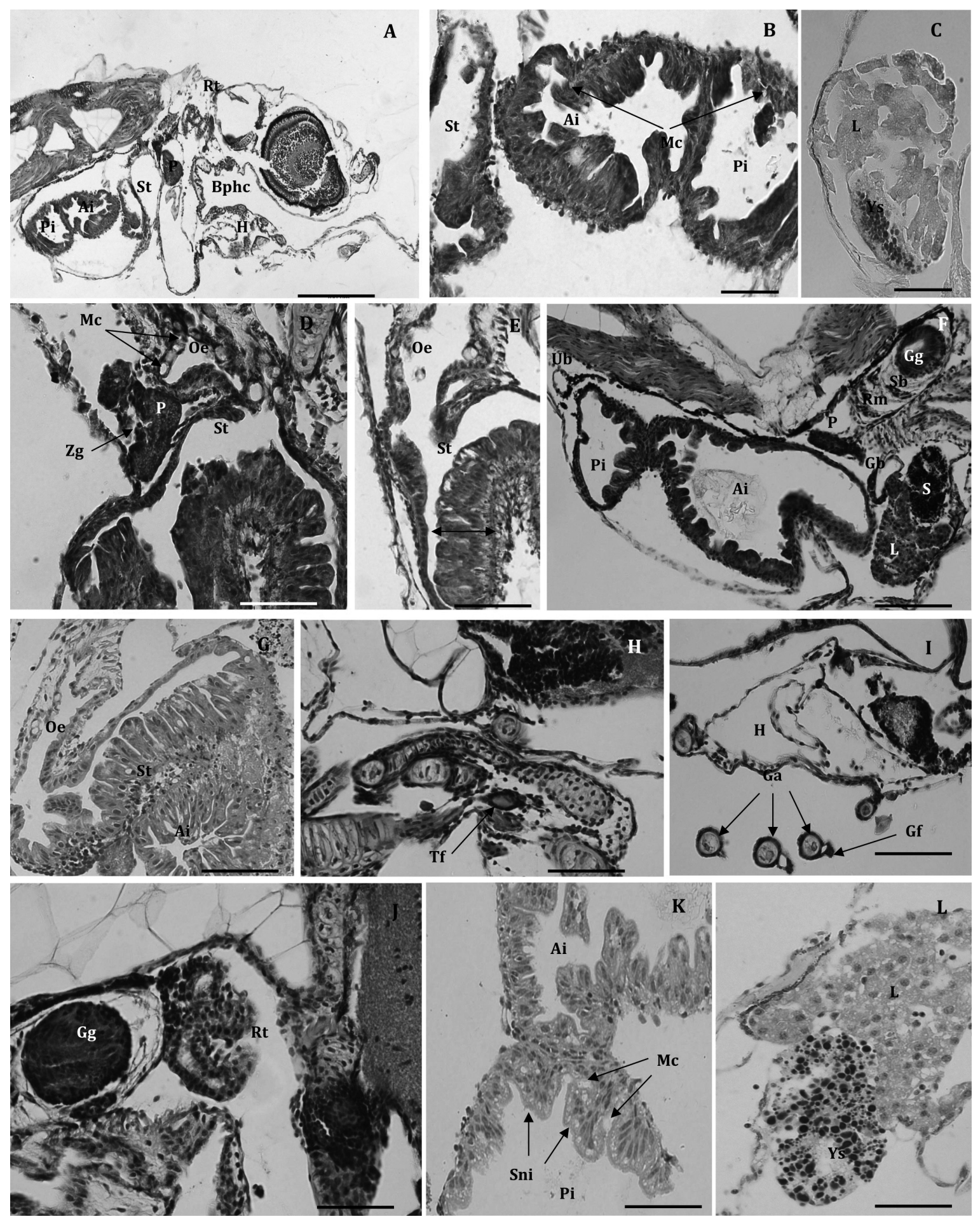

FIG. 2. - Histological sections of Merluccius merluccius larvae between 9 and 10 dph: A-E) larvae at 9 dph showing exocrine pancreas with acidophilic zymogen granules, and primary renal tubules of kidney and a completely developed gall bladder with a cuboidal epithelium. Oesophageal stratified epithelium with numerous goblet cells and an incipient stomach as a small pocket covered by a thickened mucosal layer (double arrow). Mucous cells in the intestine at $9 \mathrm{dph}$ (anterior and posterior portion). High presence of folds in the anterior and posterior intestine and residual yolk -matrix close to the functional liver, at $9 \mathrm{dph}$. Scale bar: (A) $200 \mu \mathrm{m}$, (B to E) $50 \mu \mathrm{m}$; F to L) by $10 \mathrm{dph}$ larvae showing developed swimbladder and spleen. The first thyroid follicle is seen. Primordial gill filaments and development of renal tubules are observed. Stomach lacks gastric glands and a granular residual yolk sac (scarce periblast) is still evident. Supranuclear eosinophilic inclusions in the enterocytes of the posterior intestine are detected. Hepatocytes showing granular and vacuolated cytoplasm and the vascular system. Scale bar: (F to L) 50 um (Ai: anterior intestine; Bphc: buccopharyngeal cavity; Ga: gill arches; Gb: gall bladder; Gf: gill filaments; Gg: gas gland; H: heart; L: liver; Mc, mucous cells; Oe: oesophagus; P: pancreas; Pi: posterior intestine; Rt: renal tubules; Rm: Rete mirabile; Sb: swim bladder; S: spleen; Sni: supranuclear inclusions; St: stomach; Tf: thyroid follicle; Ub: urinary bladder; Ys: yolk sac; Zg: zymogen granules. 

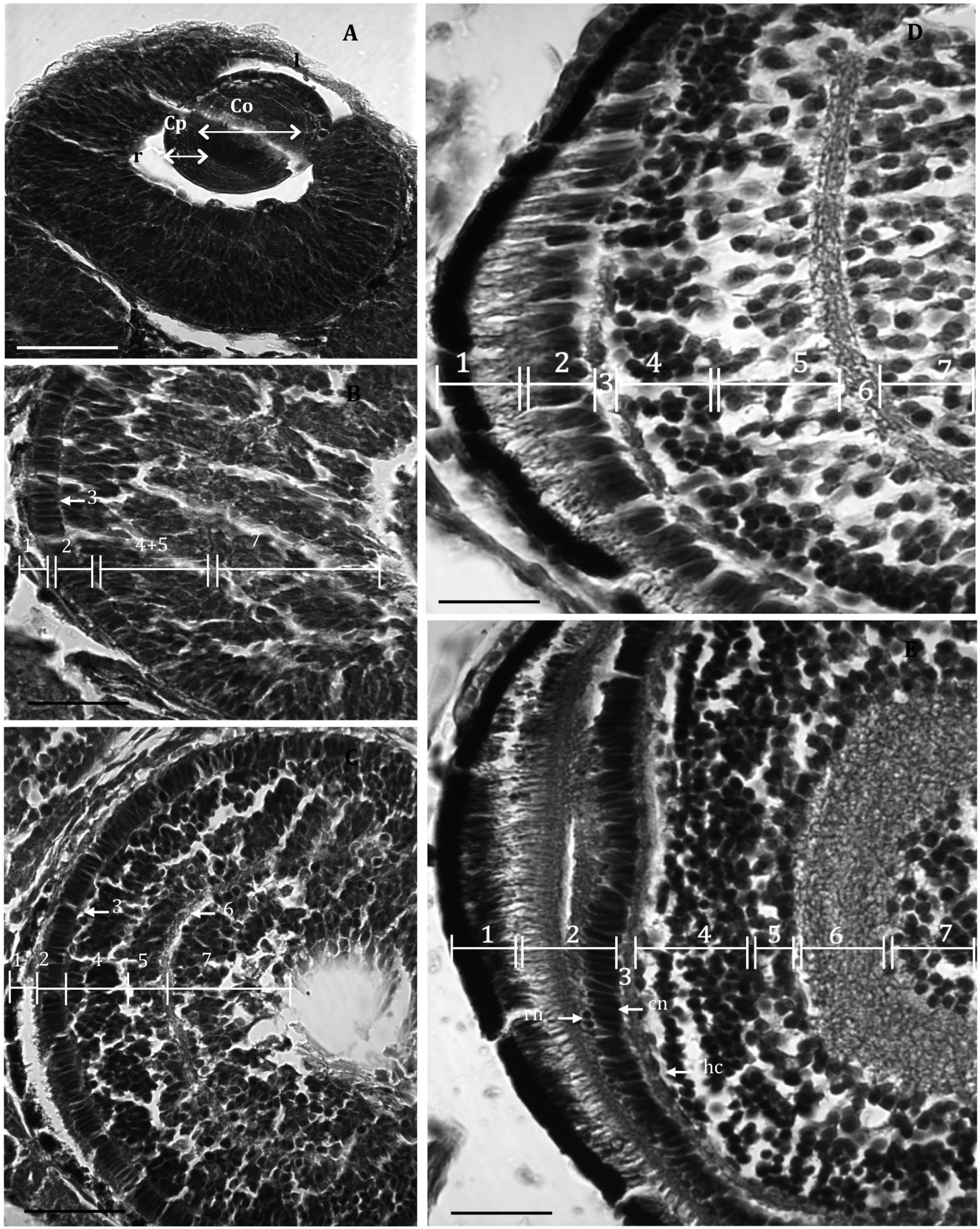

FIG. 3. - Histological development of the retina in hake larvae during endo-exotrophic phase: A) hake larvae at 1 dph showing lens composed of a outer part or capsule and an inner core region. A developing retina composed of undifferentiated cells was clearly distinguished. Scale bar: $50 \mathrm{um}$; B) larvae at $2 \mathrm{dph}$ showing different retinal layers: pigmented epithelium (1), neuroretina composed of three radially arranged layers, the outer nuclear layer (2), the inner nuclear layer (4+5), and the ganglion cell layer (7). Between (2) and (4+5) a developing outer plexiform layer (3) was distinguished. Scale bar: $20 \mu \mathrm{m} ; \mathrm{C}$ ) on day 4 hake larvae showed a developing retina: the choroidal melanocytes layer (1) followed by the photoreceptor layer (2) and an inner nuclear layer which two substrata, the bipolar (4) and amacrine (5) cell layers and a ganglion cell layer (7). Between the (5) and (7), an incipient inner plexiform layer (6) had developed. Scale bar: $20 \mu \mathrm{m}$; D) larvae at 6 dph showing a considerable thickening of the neuroretina ( 2 to 7$)$ and of the pigmented epithelium (1). Scale bar: $20 \mu \mathrm{m} ; \mathrm{E})$ by 9 dph hake larvae showing a full developed retina with a thick and dark eyecup (1) due to numerous melanin granules in the pigment epithelium of the sclera. Following the pigmented layer, photoreceptor layer with two cell types, cones and rod precursor cells, could be detected. The inner nuclear layer made of three substrata, the horizontal, bipolar (4) and amacrine (5) cell layers were also detected. Between the amacrine and ganglion cell, a prominent inner plexiform layer could be distinguished. Scale bar: 20 um (1: choroidal melanocytes, 2: photoreceptor; 3: outer plexiform; 4: bipolar cells; 5: amacrine cells; 6: inner plexiform; 7: ganglion cells; cn: cone nucleus; Co: core; Cp: capsule; hc: horizontal cells; l: lens; r: retina; rn: rod nucleus). 
to the pancreas. The liver was constituted of irregularshaped basophilic cells with a round nucleus and a prominent nucleolus. The biliary system develops from liver primordium cells. Bile canaliculi are often dilated during the liver differentiation, and disappear shortly before mouth opening, when the canaliculi become elongated and choledochus cells are differentiated. The opening of the bile duct into the anterior intestine, just after the pyloric sphincter, was visible from 3-4 dph. At this time, the gall bladder and ductuscholedochus were visible and lined by a squamous epithelium, which appeared flattened and thin when the bladder was distended. Mouth and anus were closed at $4 \mathrm{dph}$ and intestinal loops started to develop. At 1 $\mathrm{dph}$, the primordial swim bladder appeared attached to the dorsal part of the incipient gut, with columnar epithelial cells and showing vascular spaces ventrally. A very fast development of the gas gland and rete mirabile was observed in hake larvae from $4 \mathrm{dph}$. Gill anlage was discernible at $1 \mathrm{dph}$ with differentiation of primordial gill filaments from $4 \mathrm{dph}$. In newly hatched larvae, the pericardial cavity was evidenced as a tubular structure located cephalically to the coelomic cavity and ventrally to the gill anlage. In 4 dph larvae the four heart compartments (atrium, venous sinus, auricle and ventricle) were discernible and developing with a sketch of the ventricular trabeculae and valve. Primordial pronephric haematopoietic cells and the first renal corpuscle were observed in hake larvae from $4 \mathrm{dph}$. At this time spleen anlage was also detected (Table 1; Fig. $1 \mathrm{D}-\mathrm{G})$.

In hake larvae, stage 2 , or the endo-exotrophic phase, starts from $6 \mathrm{dph}$ with the opening of the mouth and the anus, and it was characterized by the coexistence of endo-exogenous food sources. During the process of resorption, yolk mass adopted a progressive heterogeneous granular acidophilic appearance (its affinity to VOF-dyes changed from Light green to Orange G) (Fig. 2H and I). Such staining characteristics prevailed until final yolk resorption, which occurred in hake larvae after $10 \mathrm{dph}$, in conjunction with the oil globule exhaustion and the appearance of hepatic, pancreatic and biliary functionality. In hake larvae from 5 to $6 \mathrm{dph}$, the opening mouth differentiated into upper and lower functional-movable jaws (Fig. 1I). From this time, the larvae already had a developed digestive tract, without a functional stomach gastric region, but with a noticeable gut regional specific differentiation. The buccopharynx communicated with the anterior intestine through a short oesophagus with a rather narrow lumen. Two different regions were distinguished in the oesophagus on the basis of the histological features of their mucosa: an anterior region lined by a pseudostratified, ciliated epithelium, and a dilated posterior region lined by a simple, cuboidal epithelium, from which the future stomach would originate and circular smooth muscle fibres were visible in the oesophagus wall (Fig. $1 \mathrm{~J}, \mathrm{~K})$. The pyloric sphincter developed, separating the future stomach from the anterior portion of intestine, which shows the PAS-positive epithelial brush border. A gas-filled swimbladder was first seen in hake larvae at the beginning of exogenous feeding. Most systems, organs and tissues (digestive and accessory glands, swim bladder, thyroid follicle, kidney, spleen, gills, eyes, heart, fins, etc.) were well differentiated and under progressive development in hake larvae at $10 \mathrm{dph}$. At this time, a remaining acidophilic yolk sac with cytoplasmic vacuoles (neutral lipid droplets), glycogen granules and coalescing yolk proteins was still discernible and connected (residual yolk) to the functional liver (Table 1; Fig. 2A-L).

Summarized histochemical results indicate the presence of neutral glycoconjugates, glycogen and proteins in the yolk sac and in the liver. Acidic glycoproteins were weakly detected in basophilic exocrine pancreas, which contained abundant acidophilic protein zymogen granules (Table 2). Digestive epithelium contained a weak presence of neutral and acidic (carboxylated and sulphated) glycoconjugates. Mucous cells detected in buccopharyngeal cavity, oesophagus and intestine synthesize and secrete neutral and acidic mucins, especially carboxylated ones, and few strongly sulphated glycoproteins. Glycogen was detected in the yolk sac, hepatocytes (Table 2), stomach epithelium and within intestinal enterocytes (Table 3). Proteins, especially rich in arginine, cysteine and cystine were located in stomach epithelium and in enterocytes of the oesophagus and anterior intestine. Eosinophilic supranuclear inclusions in the enterocytes of the posterior intestine were noticeable around 9 to $10 \mathrm{dph}$ (Table 4) and contained abundant proteins rich in tryptophan, arginine, cysteine and cystine. The oil globule from the yolk sac and droplets or vacuoles located in the digestive tract or within the liver contained neutral lipids, which are dissolved during histological procedures.

\section{Eye development}

During the lecitotrophic phase- 1 of the European hake larvae ( $0-5 \mathrm{dph})$, layers of eye and cell constituents grow considerably (Table 1; Fig. 3). In 1 dph larvae, the eye was composed of an eyecup made of 3 precursor layers: the sclera (white part), the choroidea (dark unreflective layer) and the developing retina (light receptors). The cornea was at an early stage of differentiation. The lens was composed of an outer part made of 3 capsule layers of flattened lens cells surrounding an inner core. Pigmented epithelium was composed of a single layer of flattened epithelial cells without pigments at $1 \mathrm{dph}$. From $2 \mathrm{dph}$ onwards, several retina layers differentiated and increased in number and thickness. Owing to the presence of melanin granules in the sclera epithelium, the eyecup appeared dark. These pigment cells had protrusions that extended into the photoreceptor layer. Another radial arranged retina layer or neuroretina was visible in hake larvae at $2 \mathrm{dph}$. The neuroretina contained the outer nuclear layer with developing cone photoreceptors, the inner nuclear layer 
TABLE 2. - Histochemical distribution of glycoconjugates and proteins in Merluccius merluccius larvae from hatching until 6 dph. Reaction colour intensity: 0 , negative; 1 , weak; 2 , moderate; 3 , strong.

\begin{tabular}{lccccc}
\hline & $\begin{array}{c}\text { Neutral } \\
\text { glycoconjugates }\end{array}$ & $\begin{array}{c}\text { Carboxylated } \\
\text { glycoconjugates }\end{array}$ & $\begin{array}{c}\text { Sulphated } \\
\text { glycoconjugates }\end{array}$ & Glycogen & Proteins \\
\hline Yolk sac/oil globule & $2-3 / 0$ & $0 / 0$ & $0 / 0$ & $1 / 0$ & $3 / 3$ \\
Liver/hepatocytes & $1-2$ & $0-1$ & 0 & $2-3$ & 2 \\
Exocrine pancreas/zymogen granules & $1 / 1$ & $0-1 / 0-1$ & $0-1 / 0-1$ & $0 / 0$ & $3 / 3$ \\
\hline
\end{tabular}

TABLE 3. - Histochemical distribution of glycoconjugates in oesophagus, stomach and intestine of the Merluccius merluccius larvae at 10 dph. Reaction colour intensity: 0 , negative; 1 , weak; 2 , moderate; 3 , strong.

\begin{tabular}{|c|c|c|c|c|}
\hline Neutral g & glycoproteins & Carboxylated glycoproteins & Sulphated glycoproteins & Glycogen \\
\hline \multicolumn{5}{|l|}{ Oesophagus } \\
\hline Epithelium & $0-1$ & $0-1$ & $0-1$ & 0 \\
\hline Mucous cells & $0-1$ & $2-3$ & $1-2$ & 0 \\
\hline \multicolumn{5}{|l|}{ Stomach } \\
\hline Epithelium & $0-1$ & 2 & 0 & 1 \\
\hline \multicolumn{5}{|l|}{ Intestine } \\
\hline Epithelium/enterocytes & $0-1$ & 1 & $0-1$ & 1 \\
\hline Mucous cells & $1-2$ & 3 & 1 & 0 \\
\hline Supranuclear inclusions/posterior intestine & 0 & $<0-1$ & 0 & 0 \\
\hline
\end{tabular}

TABLE 4. - Histochemical distribution of proteins in oesophagus, stomach and intestine of the Merluccius merluccius larvae at $10 \mathrm{dph}$. Reaction colour intensity: 0 , negative; 1 , weak; 2 , moderate; 3 , strong.

\begin{tabular}{|c|c|c|c|c|c|}
\hline Gene & eral proteins & Cysteine & Cystine & Tryptophan & Arginine \\
\hline \multicolumn{6}{|l|}{ Oesophagus } \\
\hline Epithelium & $0-1$ & 2 & 2 & 0 & $1-2$ \\
\hline Mucous cells & $0-1$ & $2-3$ & 2 & $0-1$ & 0 \\
\hline \multicolumn{6}{|l|}{ Stomach } \\
\hline Epithelium & $1-2$ & $0-1$ & $1-2$ & $0-1$ & 2 \\
\hline \multicolumn{6}{|l|}{ Intestine } \\
\hline Epithelium/enterocytes & 2 & 1 & $1-2$ & $0-1$ & $0-1$ \\
\hline Mucous cells & 0 & $0-1$ & 2 & 0 & 1 \\
\hline Supranuclear inclusions/posterior intestine & 3 & $2-3$ & 2 & $2-3$ & $2-3$ \\
\hline
\end{tabular}

made of somata of the future second-order neurons, and the ganglion cell layer. Between the outer and inner nuclear layers, development of the outer plexiform layer was distinguished. In $4 \mathrm{dph}$ larvae lens diameter and thickness of the retina layers increased considerably. The inner nuclear layer was made of two substrata; the bipolar and amacrine cell layers. Between the amacrine and ganglion cell layers an incipient inner plexiform layer was developing (Fig. 3A-C).

During the endo-exotrophic phase-2 (6-10 dph), the eyes had the neuroretina layer and the pigmented epithelium almost fully developed from 6 dph onwards. Due to the presence of two photoreceptor cell types, cones and precursor rod cells, a sufficiently developed retina was visible at $9 \mathrm{dph}$. Interestingly, the inner nuclear layer was fully developed at this stage and made of three substrata: horizontal, bipolar and amacrine cell layers. Finally, a prominent inner plexiform layer between the amacrine and ganglion cell layers was also distinguished in larvae from 9 dph (Fig. 3D, E).

\section{DISCUSSION}

Recent years have seen growing interest in culturing gadid species on an industrial scale. Today, the availability of healthy broodstocks of European hake in captivity (Norway and Spain) is recognized as a crucial factor to determine fish yolk quality and a necessary prerequisite for optimal growth and successful larval survival in rearing conditions (Bjelland and Skiftesvik 2006, Iglesias et al. 2010). However, massive production of the European hake, Merluccius merluccius, is still limited because of hatchery problems, mostly the high mortalities detected during larval rearing under intensive larviculture system, particularly at the moment of transition from endogenous to exogenous feeding and weaning to artificial diets. In hake species, as in most reared teleost fishes, the transitional feeding period is the moment when the feeding ability of the fish larvae is being developed and larvae start to eat (exogenous food) with some endogenous reserves still present to meet energetic demands of prey capture (Bjelland and Skiftesvik 2006, Gisbert et al. 2008, Zambonino-Infante et al. 2008). Another factor related to larval mortality of hake species is the failure of the lipid droplet absorption (Bustos et al. 2007) of unknown origin. Upon hatching, European hake larvae, like those of many other fish species (Kawamura 1984, Blaxter 1996, Roo et al. 1999, Falk-Petersen 2005), are fairly undeveloped and do not have functional eyes or digestive systems. The energy needed for metabolism, swimming activity and growth is obtained from the yolk-sac reserves. The lipid globule, located in the posterior part of the yolk sac, is likely the major source of energy for sustaining larvae during 
the transition of exogenous feeding, because it is the most important source of endogenous triacylglycerols. However, stress or nutritional status of broodstocks may affect the mechanical absorption of the lipid droplet and available fatty acids, and it can produce abnormalities in the intestinal mucosa of larvae and/or in the formation of the yolk syncytial layer, and lead to high larval mortalities (Deplano et al 1991, Falk-Petersen 2005, Bustos et al. 2007).

In the European hake larval development, within projections of the periblast, protein granules, lipid droplets and glycogen particles are abundant and they are probably formed from the precursor materials absorbed from the yolk and derived from maturing oocytes. Histochemical studies of different fish species have shown considerable similarities in yolk composition of maturing oocytes and that of yolk-sac larvae (Sarasquete et al. 1993a,b, 1996, 2002a,b, Ortiz-Delgado et al. 2006, 2008). In newly hatched hake larvae there is not a well-developed blood supply surrounding the yolk sac. Progressively, during the endo-exotrophic phase, as in many other fish larvae (Stroband and Dabrowski 1981, Falk-Petersen 2005), yolk products apparently can pass directly from the surface of the periblast into a subdermal sinus, which extends around the gut, and into the finfold. Yolk products can also go directly to the liver to be metabolized, since hepatic tissue is closely associated with the periblast (Falk-Petersen 2005). At the end of the endo-exogenous phase of the European hake larvae, a remaining acidophilic and heterogeneous granular yolk sac (glycogen, proteins, lipids) was still detected and directly connected with the functional liver (at 10 dph). An important function of the yolk syncytial layer or periblast that plays critical roles in morphogenesis throughout embryonic and early larval development is the transport of nutrients from the yolk to the embryonic cells and larval tissues. The periblast is necessary for hydrolysis of yolk material and the transfer of nutrients from the yolk cell to the embryonic blastoderm and larval tissues. The periblast can participate in resorption and/or digestion of yolk, during embryogenesis and development, because of the presence of enzymatic activities (Lentz and Trinkaus 1967, Walzer and Schönemberger 1979, Sarasquete et al. 1996). The extra-embryonic yolk syncytial layer and embryonic germ layer progenitor cells interact to coordinate the movements required for proper cell fate specification and tissue morphogenesis. Several genes coding for enzymes involved in early metabolism and nutrition-related functions are expressed exclusively within the yolk syncytial layer (Carvalho and Heisenberg 2010).

At hatching, the digestive tract of the different fish species (Kuz'mina and Gel'man 1998, Falk-Petersen 2005, Gisbert et al. 2008), as reported in this study for reared European hake, appears as a straight and undifferentiated tubular segment lying dorsally to the yolk sac. It is well known that most teleost fishes start exogenous feeding when their digestive tracts are not fully developed but functional (Dinis et al. 1999, Ribeiro et al. 1999, Zambonino-Infante et al. 2008, between others). The differentiation of the digestive tract of the European hake larvae into morpho-histologically distinct regions, namely the buccopharynx, oesophagus, presumptive stomach and intestinal portions, was well established at $6 \mathrm{dph}$. Possible functional capabilities can be inferred from the structural features of the epithelial cells lining the different segments of the alimentary canal. The PAS-positive brush border and cytoplasmic granules in the epithelial layer of the intestine during the endo-exogenous feeding phase may suggest, as described in other fish species (Sarasquete et al. 1995, Falk-Petersen 2005), that hake larvae are able to digest and absorb carbohydrates at the time of first feeding. The time in which mucous cells appear varies between species, but usually coincides with the mouth opening and the first exogenous feeding. Mucus secretion plays important roles, such as absorption of easily digestible substances such as disaccharides and short-chain fatty acids, pre-gastric digestion, lubrication, protection of the digestive mucosa, and pathogenic and toxic defences, among other major physiological functions, thanks to the production of neutral and acidic mucins (Sarasquete et al. 1995, 1996, 1998, 2001, ZamboninoInfante et al. 2008). In hake larvae, digestive mucous cells were first seen in the oesophagus and later in the intestine, during the endo-exogenous feeding transition phase, and these goblet cells synthesize and secrete neutral, carboxylated and sulphated glycoconjugates, as described in many different fish species (Falk-Petersen 2005, Gisbert et al. 2008).

The presence of unstained vacuoles in the anterior intestine mucosa after the beginning of exogenous feeding is an indicator of luminal absorption and storage of lipids because of poor lipid metabolism, which improves with larval growth (Deplano et al. 1991, Sarasquete et al. 1995). Simultaneously, with the starting of exogenous feeding, lipid absorption is observed in the anterior intestine, suggesting that enterocytes are able to process and transfer the fat content of ingested food from a very early developmental stage, as observed in the present study. During the endo-exotrophic feeding phase of European hake larvae, protein absorption was visible shortly after first feeding as supranuclear protein vesicles in the enterocytes of the posterior intestine. Those vesicles are involved in the pinocytotic uptake of proteins, which are subsequently digested intracellularly, suggesting that this is a transient mechanism for protein digestion related to immaturity of the digestive tract, and particularly to the absence of a gastric stomach (Segner et al. 1994, Sarasquete et al. 2005, FalkPetersen 2005, Gisbert et al. 2008, Zambonino-Infante et al. 2008). At the moment of mouth opening in hake larvae (from $6 \mathrm{dph}$ ), the liver, gall bladder and exocrine pancreas were already differentiated, developed and functional and connected to the intestine by the bile and pancreatic ducts, respectively. Eosinophilic zymogen granules, precursors of pancreatic enzymes, are accumulated within the exocrine pancreas before 
mouth opening, indicating a genetically programmed rather than dietary-induced differentiation (Ribeiro et al. 1999, Zambonino-Infante et al. 2008).

In European hake larval development, prey capture became guaranteed early, because of the early development of gut, jaws, fins, swim bladder, teeth and sensory organs (Mas-Riera 1991, Palomera et al. 2005, Bjelland and Skifftesvik 2006, Morote et al. 2011, Sánchez et al. 2011). During the endo-exotrophic feeding phase of hake larvae, gut widening takes places, which is a factor as important as mouth size for determining the ingestion of prey. As larval development advances, folds appear in the gut, providing additional space for accumulating prey and favouring food retention. A gas-filled swim bladder was first seen in hake larvae during the endo-exogenous feeding phase (at $9 \mathrm{dph}$ ). The presence of the swim bladder is important during larval fish development, as it controls buoyancy and makes swimming activity and prey capture more energy efficient. The failure of swim bladder inflation is associated with reduced growth, skeletal deformities and high mortalities caused by buoyancy problems and ineffective foraging (Falk-Petersen 2005, Bjelland and Skiftesvik 2006).

Vision is the sense most used by fish larvae to feed, and changes in feeding behaviour might depend primarily on functional eyes (Blaxter, 1986, Kawamura 1984, Kawamura and Washiyama 1989, Mas-Riera, 1991). An important aspect of larval development related to the feeding success of M. merluccius is its well-developed visual acuity from its earliest stages, which must help to detect a wide range of prey, or prey of the same size from a greater distance (Morote et al. 2011). The appearance of functional photoreceptors (cones and rods) in fish retina (Blaxter 1986, Kawamura 1984, Kawaumura and Washiyama 1989, Kawaumura et al. 1984, 2003, Mas-Riera 1991, Margulies 1997) can be related to higher visual sensitivity, and it is very important during adaptation to lower light intensities, especially when fish shift from pelagic environments to bentho-pelagic environments (MasRiera 1991, Morote et al. 2011). The first indicator of functional eyes is the occurrence of melanin within the eyecup, first seen in hake larvae at $4 \mathrm{dph}$. Pigmentation was accomplished by neuroretinal differentiation. The sequence of cellular differentiation in the neuroretina of hake larvae follows the basic pattern seen in other vertebrates (Powers and Raymon 1990, Haacke et al. 2001, Falk-Petersen 2005): first differentiation of cone photoreceptors and ganglion cells (hake $4 \mathrm{dph}$ ), and consecutively neurons of the inner nuclear layer showing specific sub-stratification (hake $6 \mathrm{dph}$ ) and finally developing rods (hake $9 \mathrm{dph}$ ). In different fish species, rod photoreceptors have been reported between 5 and 29 dph (Hadedorn and Fernald 1992, Branchet and Bremiller 1984, Haacke et al. 2001). It is well known that appearance of pigmentation and developed rod-type photoreceptors in fish retina is indicative of fully developed and functional eyes (Blaxter 1986,
Kawamura et al. 1984, 2003, Falk-Petersen 2005). In hatchery-reared hake larvae, rods were well developed at 9 to $10 \mathrm{dph}$ (4.30 mm TL). Recently, Morote et al. (2011) suggested that in the smallest wild-caught hake larvae $(2.4 \mathrm{~mm})$, the complete functionality of the retina was questionable, because no pigment migration was observed. However, retinal pigment migration was detected in larvae larger than $3 \mathrm{~mm}$, which had a pure cone-like retina; presumptive rod precursor cells in the outer nuclear layer were first reported in wild-caught hake larvae of $7 \mathrm{~mm} \mathrm{TL}$. According to several authors (Blaxter 1986, Kawamura 1984, Morote et al. 2011), the enlargement of the lens and the increase in the cone-like receptors strongly determine the increase in optical sensitivity during larval growth.

In summary, at the end of the endo-exogenous phase of European hake larvae, a remaining acidophilic and heterogeneous granular yolk sac (glycogen, proteins, lipids) was still detected and directly connected with the functional liver (at $10 \mathrm{dph}$ ). The opening of the mouth, functionality of the eyes, gut and associated digestive organs (liver, biliary system, pancreas, mucous secretions, absorption, digestion and storage processes, etc.) and swim bladder-inflation were detected at this time. The development of eyes and particularly the typical pigmentation pattern and an early differentiation of retinal photoreceptors (cones, rods) in hake larvae, at the onset of exogenous feeding, could have important implications for successful hake production. The parallelism between the development of digestive and visual systems and the importance of both these systems for the beginning of prey capture and predator avoidance is highlighted, because major and very noticeable retinal ontogenetic changes are observed during the endo-exotrophic feeding phase of hatcheryreared European hake development, and particularly between 6 and $10 \mathrm{dph}$. These ontogenetic remarks could be related to potential improvements in hatchery management, contributing to successful larval rearing.

Interestingly, a high percentage of hake larvae showed non-adherence of the oil globule (freely moving in the yolk and not located in the posterior part of the yolk sac), and parallel high mortalities were evidenced in the reared fish from $10 \mathrm{dph}$ onwards. In consequence, further investigations are still necessary in order to study and guarantee optimal zootechnical rearing conditions (i.e. feeding [live/inert] protocols for broodstocks and larvae), optimal rearing temperature and adequate light intensity requirements for larval development, successful feeding-nutrition and higher growth, and especially to produce healthy larvae of this commercially important fish species with good survival rates.

\section{ACKNOWLEDGEMENTS}

The authors are grateful to Isabel Viaña for her valuable technical assistance. This work was partially funded by ICMAN-CSIC (Puerto Real, Cádiz, Spain) 
and IEO (CULMER Research Project). Broodstock and hatchery-reared European hake larvae were maintained in fish marine culture installations (IEO, Vigo, NW, Spain) under proper healthy conditions.

\section{REFERENCES}

Alheit J., Picher T.J. (eds.) 1995. Hake: fisheries, ecology and markets. Fish and fisheries series 15. Chapman \& Hall, London, 487 pp.

Arneri E., Morales-Nin B. 2000 . Aspects of the early history of the European hake from the central Adriatic. J. Fish Biol. 46: 1368-1380.

Bjelland R.M., Skiftesvik A.B. 2006. Larval development in European hake (Merluccius merluccius $\mathrm{L}$ ) reared in a semi-intensive culture. Aq. Res. 37: 1117-1129.

Blaxter J.H.S. 1986. Development of sense organs and behaviour of teleost larvae with special reference to feeding and predator avoidance. Trans. Am. Fish. Soc. 115: 98-114.

Bozzano A., Catalan I.A. 2002. Ontogenetic changes in the retinal topography of the European hake, Merluccius merluccius: implications for feeding and depth distribution. Mar. Biol. 141: 549-559.

Branchet T., Bremiller R. 1984. The development of photoreceptors in the zebrafish, Brachiodanio rerio. J. Comp. Neur. 224: 116-122.

Bustos C.A., Landaeta F., Bay-Schmith E., Lewis R., Moraga X. 2007. Effects of temperature and lipid droplet adherence on mortality of hatchery-reared southern hake, Merluccius merluccius larvae. Aquaculture 270: 535-540.

Carvalho L., Hesberg C.P. 2010. The yolk syncytial layer in early zebrafish development. Trends Cell Biol. 20: 586-592.

Casey J., Pereiro J. 1995. European hake (M. merluccius) in the Nort-east Atlantic. In. Alheit J and Pitcher, T.J (eds.), Hake, fisheries, ecology and markets. Fish and fisheries series 15. Chapman \& Hall, London, pp: 142-147.

Deplano M., Diaz J.P., Connes R., Kentouri-Divamach M., Cavalier F. 1991. Appearance of lipid-absorption capacities in larvae of the sea bass, Dicentrarchus labrax during transition to the exotrophic phase. Mar. Biol. 108: 361-371.

Dinis M.T., Ribeiro L., Soares F., Sarasquete C. 1999. A review on the cultivation potential of Solea senegalensis in Spain and Portugal. Aquaculture 176: 27-38.

Falk-Petersen I.B. 2005. Comparative organ differentiation during early life stages of marine fish. Fish Sellfish Inmunol. 19: 397-412.

FAO. 2005. Review of the state of world marine fishery resources. FAO. Fish Tech. Pap., 457: 235 pp.

Gisbert E., Ortiz-Delgado J.B., Sarasquete C. 2008. Nutritional cellular biomarkers in early life stages of fish. Histol. Histopathol. 23: $1525-1539$.

Groison, A.L. 2010. Male reproductive biology of the European hake, Merluccius merluccius. Ph. D. thesis, Univ. Bergen (Norway), $88 \mathrm{pp}$.

Haacke C., Martin H., Melzer R.R., Gebhart H., Smola U. 2001. Fine structure and development of the retina of the grenadier anchovy, Coilia nasus (Engraulidae, Cupleiformes). J. Morphol. 248: 41-55

Hadedorn M., Fernald R.D. 1992. Retinal growth and cell addition during embryogenesis of the teleost, Haplochromis burtoni. J. Comp. Neur. 321: 193-208

Iglesias J., Lago M.J., Sánchez F.J., Cal R. 2010. Short communication: Capture, transport and acclimation to captivity of the European hake, Merluccius merluccius: preliminary date on feeding and growth. Aq. Res. 41: 607-609

Kawamura G. 1984. The visual cell morphology of Pagrus pagrus and its adaptative changes with shift from pelagic and benthic habits. Bull. Jpn. Soc. Sci. Fish. 50: 1975-1980.

Kawamura G., Washiyama N. 1989. Ontogenetic changes in behaviour and sense organ morphogenesis in largemouth bass and Tilapia nilotica. Trans. Am. Fish. Soc. 118: 203-213

Kawamura G., Mukay Y., Ohta H. 1984. Changes in the visual threshold with development of rods in ayu, Pecoglossus altivelis. Nip. S. Gak. 50: 2133.

Kawamura G., Masuma S., Tezuka N., Koiso M., Jimbo J., Namba
K. 2003. Morphogenesis of the sense organs in the bluefin tuna, Thunnus orientalis. In: Browman and Skiftesvik (eds.), The big fish band. N-5817. Bergen, Norway, pp: 123-135.

Kuz'mina V.V., Gel'man G.A. 1998. Traits in development of the digestive functions in fishes. J. Ichthtyol. 38: 106-115.

Land M.F., Nilsson D.E. 2002. Animal eyes. Oxford University Press, Oxford, 244 pp.

Last J.M. 1980. The food of twenty species of fish larva in the westcentral North Sea. Fish Res. 60: 1-44.

Lentz T.L., Trinkaus P. 1967. A fine structure of cytodifferentiation during cleavage, blastula and gastrula stages of Fundulus heteroclitus. J. Cell Biol. 32: 121-137.

Lloris D., Matallanas J., Oliver P. 2005. Species catalogue for fishery Purposes. Hakes of the World. FAO, Roma, $57 \mathrm{pp}$.

Martoja, R. Martoja-Pierson M. 1970. Técnicas de Histología Animal. Ed Toray-Masson, Barcelona (Spain), $350 \mathrm{pp}$.

Margulies S. 1997. Development of the visual system and inferred performance capabilities of larval and early juvenile scombrids. Mar. Fresh. Behav. Physiol. 30: 203-213.

Mas-Riera J. 1991. Changes during growth in the retinal structure of three hake species, Merluccius (Teleostei; Gadiformes) in relation to their depth distribution and feeding. J. Exp. Mar. Biol. Ecol. 152: 91-104.

Morales-Nin B., Bjelland R.M., Moksness E. 2005. Otolith microstructure of a hatchery reared European hake (Merluccius meruccius). Fish. Res. 74: 300-305.

Morote E., Olivar M.P., Pankhurst P.M., Villate F., Uriarte I. 2008. Tropic ecology of blue tuna Auxis rockei larvae and ontogeny of feeding-related organs. Mar. Ecol. Prog. Ser. 353: 243-254.

Morote E., Olivar M.P., Bozzano A., Villate F., Uriarte I. 2011. Feeding selectivity in larvae of the European hake (Merluccius merluccius) in relation to ontogeny and visual capabilities. Mar. Biol. 158(6): 1349-1361.

Murua H., Saborido-Rey F. 2003. Female reproductive strategies of marine fish species of the North Atlantic. J. Northw. Atl. Sish. Sci. 33: 23-31

Ortiz-Delgado J.B., Ruane N.M., Pouçao P., Dinis M.T., Sarasquete C. 2006. Thyroid gland development in Senegales sole, Solea senegalensis Kaup 1858 during early life stages: a histochemical and immunohistochemical approach. Aquaculture 260: 346-353.

Ortiz-Delgado J.B., Porcelloni S., Fossi C., Sarasquete C. 2008. Histochemical characterization of the swordfish, Xiphias gladius oocytes. Sci. Mar. 72(3): 549-568.

Olivar M.P., Quílez G., Emelianov M. 2003. Spatial and temporal distribution and abundance of European hake, Merluccius merluccius, eggs and larvae in the Catalan coast (NW Mediterranean). Fish Res. 60: 321-331.

Oliver P., Massutí E. 1995. Biology and fisheries of western Mediterranean hake (Merluccius merluccius).. In: Alheit J, Pitcher TJ (eds.), Hake: fisheries, ecology and markets. Chapman \& Hall, London, pp: 181-202.

Omura Y., Uematsu K., Tachiki H., Furukawa K., Satoh H. 1997. Cone cells appear also in retina of eel larvae. Fish. Sci. 63: 1052-1053.

Palomera I., Olivar M.P., Morales-Nin B. 2005. Larval development and growth of the European hake in the NW Mediterranean. Sci. Mar. 69: 221-258.

Pearse, A.G.E. 1985. Histochemistry: Theorethical and Applied. 4th Ed. Churchill, Livingstone, Edinburg, 1055 pp.

Powers M.K., Raymond P.A. 1990. Development of the visual system. In Douglas, R.H., Djamgoz (eds.). The visual system of fish. Chapman and Hall, London, pp. 419-442.

Recassens L., Lombarte A., Morales-Nin B., Torres G. 1998. Spatiotemporal variation in the population structure of the European hake in the NW Mediterranean. J. Fish Biol. 53: 387-401.

Recassens L., Chiericoni V., Belcari P. 2008. Spawning pattern and bath fecundity of the European hake (Merluccius merluccius, Linnaeus, 1758) in the western Mediterranean. Sci. Mar. 72(4): 721-732.

Ribeiro L., Sarasquete C., Dinis M.T. 1999. Histological and Histochemical Characteristics during development of the Senegal sole, Solea senegalensis. Aquaculture 171: 291-306.

Roo F.J., Socorro J., Izquierdo M.S., Caballero M.J., HernándezCruz C.M., Fernandez A., Fernández-Palacios H. 1999. Development of red porgy, Pagrus pagrus visual system in relation with changes in the digestive tract and larval feeding habits. 
Aquaculture 179: 499-512.

Sandy J.M., Blaxter J.M.S. 1980. A study of retinal development in larval herring and sole. J. Mar. Biol. Ass. U.K. 60: 59-71.

Sánchez P., Sartor P., Recassens L., Ligas A., Martin J., Ranieri S., Demestre M. 2007. Trawl catch composition during different fishing intensity periods in two Mediterranean demersal fishing grounds. Sci. Mar. 71(4): 765-773.

Sánchez F.J., Otero J., Cal J.R., Lago M.J., Gómez C., Iglesias J. 2011. The first spontaneous spawning of European hake, Merluccius merluccius L: Characteristics of eggs and early larval stages. Aqua. Res. (in press).

Sarasquete C., Gutiérrez M. 2005. New Tetrachromic VOF Stain (Type III-G.S) For Normal and Pathological Fish Tissues. European J. Histochem. 49(2): 105-114.

Sarasquete C., Polo A., Pascual E., Yúfera M. 1993a. Histochemistry of proteins, lipids and carbohydrates in the yolk constituents of oocytes, eggs and larvae of Sparus aurata L. Phys. Bioch. Mar. Fish Larv. 309-314.

Sarasquete C., Polo A., González de Canales M.L. 1993b. A histochemical and immunohistochemical study of digestive enzymes and hormones during the larval development of the seabream, Sparus aurata. Histochem. J. 25: 430-437.

Sarasquete C., Polo A., Yufera M. 1995. Histological and histochemical study during larval development of Sparus aurata L. Aquaculture 130: 79-92.

Sarasquete C., González de Canales M.L., Arellano J., MuñozCueto J.A., Ribeiro L., Dinis M.T. 1996. Histochemical aspects of the yolk-sac and digestive tract of the Senegal sole, Solea senegalensis. Histol. Histopatol. 11: 881-888.

Sarasquete C., González de Canales M.L, Arellano J.M., MuñozCueto J.A., Ribeiro L., Dinis M.T. 1998. Histochemical study of skin and gills of Senegal sole, Solea senegalensis larvae and adults. Histol. Histopatol. 13: 727-735.

Sarasquete C., Ribeiro L., Gisbert E., Vieira L., Dinis M.T. 2001.
Glycoconjugates in epidermal, branchial and digestive mucous cells and gastric glands of gilthead seabream, Sparus aurata, Senegal sole, Solea senegalensis and Siberian sturgeon, Acipenser baeri. Europ. J. Histochem. 45: 267-278.

Sarasquete C., Cardenas S., González de Canales M.L., Pascual E. 2002a. Oogenesis in the bluefin tuna, Thunnus thynnus L. A histological and histochemical study. Histol. Histopatol. 17: $775-788$

Sarasquete C., González de Canales M.L., Piñuela C., Muñoz-Cueto J.A., Rendon C., Mañanos E., Rodríguez-Gómez F.J., Pascual E. 2002b. Histochemical Characteristics of the vitellogenic oocytes of the bluefin, Thunnus thynnus L. Cienc. Mar. 28(4): 419-431.

Segner H., Storch V., Reinecke M., Kloas W., Hamke W. 1994. The development of functional digestive and metabolic organs in turbot, Scophthalmus maximus. Mar. Biol. 119: 35-39.

Stroband H.W.J., Dabrowski K.R. 1981. Morphological and physiological aspects of the digestive system and feeding in freshwater fish larvae. In: Fontaine, M. (ed.), Nutrition des Poissons. Edition de Centre National de la Researche Scientifique, Paris, France, pp: 353-376.

Walzer C., Schönenberger N. 1979. Ultrastructure and cytochemistry study of the yolk syncytial layer in the alevin of trout (Salmo fario trutta $\mathrm{L}$ ) after hatching. Cell Tissue Res. 196: 59-73.

Zambonino-Infante J., Gisbert E., Sarasquete C., Navarro I., Gutiérrez J., Cahu C.L. 2008. Ontogeny and physiology of the digestive system of marine fish larvae. In: Cyrino, JEO., Bureau, D. and Kapoor, B.G. (eds.), Feeding and Digestive Functions of Fish. Science Publishers, Inc, Enfield (NH), Jersey, Plymouth, pp: 281-348.

Scient. ed.: M.P. Olivar.

Received May 20, 2011. Accepted October 26, 2011.

Published online February 3, 2012. 